\title{
KEPEMIMPINAN PESANTREN DAN PERUBAHAN SOSIAL
}

\author{
Aminatuz Zahroh \\ Institut Agama Islam Syarifuddin Lumajang, Indonesia \\ E-mail: aminatuszahro@gmail.com
}

\begin{abstract}
Abstrak: Tulisan ini akan melihat pesantren sebagai lembaga pendidikan indegenious dari sudut pandang kepemimpinan. Sejatinya, penelitian tentang hal tersebut sudah lazim dilakukan. Tetapi koneksi antara kepemimpinan dengan perubahan sosial di dalam pesantren tidak banyak dilakukan, karena sejak awal pesantren selalu melakukan perubahan dengan sangat selektif dan adaptif. Selain itu, acapkali perubahan kepemimpinan di pesantren menyebabkan disparitas baru antara pesantren dengan pemangku kepentingan yang lain. Kesimpulan dari penelitian ini menyebutkan bahwa seorang pemimpin di pesantren harus menerapkan the spiritual leadership yang secara garis besar adalah berkenaan dengan upaya konsolidasi dengan niat yang suci yaitu dengan memulai dari niat diri sendiri, membangun niat secara bersama, mempertahankan niat, budaya organisasi, membangun persaudaraan dan kolaborasi serta membangun integritas yaitu dengan cara membangun integritas budaya organisasi yang sehat.
\end{abstract}

Kata Kunci: Kepemimpinan, Pesantren, Perubahan, Sosial

\section{Pendahuluan}

Kepemimpinan merupakan aspek kehidupan yang menjadi perhatian manusia sejak berabadabad yang lalu. Kepemimpinan merupakan sebuah posisi sekaligus karya luhur yang memang dibutuhkan sebagai kodrat sejarah dan fitrah peradapan. Kepimimpinan dibutuhkan untuk terkelolanya dunia dan isinya, dengan arahan yang jelas, serta keadilan yang merata. ${ }^{1}$

Pada kondisi obyektifnya kepemimpinan kurang dapat dipahami dengan baik oleh beberapa pemimpin dalam sebuah organisasi dan lembaga pendidikan. Hal ini terbukti dengan kepemimpinan yang seringkali dianggap prestise tersendiri dalam panggung kehidupan dan keinginan untuk menjadi pemimpin sering kali lebih kuat melebihi keinginan terhadap hal lain. Kepemimpinan sering kali juga menjadi titik tertinggi pencapaian seseorang setelah sukses kekayaan dan cinta.

Yulk mengemukakan "Leadership is definedbroadly to include influence processes involving determination of the group's or organization's objectives, motivating task behavior in pursuit of these objectives, and influencing group maintenance and culture". ${ }^{2}$ Kepemimpinan adalah didefinisikan secara luas sebagai proses-proses mempengaruhi, yang melibatkan penentuan sasaran organisasi atau tim kerja, memotivasi untuk memenuhi tugas agar mencapai sasaran dan mempengaruhi aktifitas kelompok dan budayanya.

Menurut Hersey dan Blanchard, "The leadership process funtion of the leader, the follower and other situational variables- $=f(I, F, S)^{3}$.'Proses kepemimpinan adalah fungsi pemimpin, pengikut dan varibel situasional lainnya $-\mathrm{K}=\mathrm{f}(\mathrm{P}, \mathrm{p}, \mathrm{s}){ }^{4}$

Istilah kepemimpinan dalam ajaran Islam dikenal dengan kata Imamah. Kepemimpinan adalah proses mempengaruhi atau memberi contoh oleh pemimpin kepada pengikutnya untuk mencapai tujuan bersama (Organisasi dan pesantren)

Istilah pemimpin dalam Islam diungkapkan dengan tujuh macam dalam Bahasa Arab yaitu: Imam, Khalifah, Malik, Wali, 'Amir, Ra'in, Sulthan, Rais serta Ulil Amri. Sedangkan al-Qur'an hanya menggunakan kata pemimpin dengan Imam dan Khalifah.

\footnotetext{
${ }^{1}$ J. Donald Walters, Herb Cohen, Dave Johnson, Great Leadership (Semarang: Dahara Prize, 2013), iii.

2 G. Yukl, Leadership In Organization (Second Edition) (Englewood Cliffs- New Jersey: Prentice Hall Inc, 1989). 5.

3 Paul Hersey dan Kennet H. Blanchard, Management of Organizational Behavior. Utilizing uman Resource (Englewood Cliffs- New Jersey: Prentice Hall Inc, 1977), 84.

${ }^{4}$ NurEfendi, Islamic Education Leadership (Yogyakarta:Kalimedia, 2015), 3-4. 
Empat hal yang menyebabkan seorang pemimpin diperlukan adalah sebagai berikut:

1. Banyak orang yang memerlukan figur pemimpin sebagai panutan

2. Perlunya seorang pemimpin yang tampil mewakili kelompoknya dalam situasi tertentu

3. Perlunya orang yang bertanggung jawab dan mengambil resiko bila terjadi hal yang tidak diinginkan dalam kelompok

4. Manusia perlu tempat untuk melakukan kekuasaan. ${ }^{6}$

Dari penjelasan di atas dapat difahami bahwa kepemimpinan pesantren merupakan proses mempengaruhi dan memberi teladan oleh kyai dan orang-orang yang diberi wewenang oleh kyai kepada santri untuk mencapai tujuan pesantren. Kepemimpinan pesantren lebih mengarah pada proses ta'dib (pendidikan) dan ta'lim (pengajaran). Dalam hal ini, disamping berperan sebagai seorang pemimpin, kyai juga berperan sebagai pendidik dan pengajar..

Lima Level kepemimpinan menurut Arvan Pradiansyah adalah sebagai berikut:

Level 1 : Memimpin dengan permintaan biasa

Pada level ini, seorang pemimpin dapat meminta bawahannya untuk melakukan sesuatu, tanpa banyak pertanyaan darinya.

Level 2 : Memimpin dengan alasan rasional

Pada level ini, seorang pemimpin berusaha meyakinkan bawahannya dengan mengemukakan alasan rasional. Hal ini biasanya dilakukan oleh pemimpin, jika mengalami kegagalan dalam melaksanakan suatu program.

Level 3 : Memimpin dengan imbalan (Reward)

Pada level ini, seorang pemimpin memberi imbalan pada bawahan, karena gagal meminta bawahannya melakukan sesuatu, bahkan disertai alasan rasionalpun tetap gagal.

Level 4 : Memimpin dengan ancaman

Seorang pemimpin masuk dalam level ini, jika gagal memberikan imbalan

Level 5 : Memimpin dengan paksaan

Level ini, merupakan level pamungkas, ketika bawahan menolak keempat level tersebut.

Oleh karena di pesantren terdapat santri yang heterogen (bermasalah dan tidak bermasalah), maka untuk level 1,2 dan 3 terbiasa dilakukan oleh para pengurus pesantren dalam menghadapi santri yang tidak bermasalah. Sedangkan level 4 dan 5 terbiasa dilakukan untuk menghadapi anak yang bermasalah.

Dalam pengangkatan keluarga kyai sebagai pengurus pesantren, seringkali dilaksanakan untuk memberikan pengalaman dalam kepemimpinan dan manajemen pesantren dan mengayomi ummat, meskipun belum nampak memiliki keahlian dan bakat alami dalam memimpin.

Sedangkan pengangkatan santri sebagai pengurus pesantren, banyak didasarkan pada keahlian, pengabdian dan pengalaman dalam memimpin. Untuk menjaga regenerasi kepengurusan pesantren, maka santri dilatih berkecimpung dalam kepengurusan pesantren dari level yang paling bawah hingga level paling atas, yaitu kepengurusan kamar, kepengurusan kompleks,kepengurusan asrama, kepengurusan lembaga-lembaga di bawah pesantren, kepengurusan madrasah diniyah, bahkan kepengurusan sekolah/madrasah formal.

\section{Dasar Kepemimpinan Pesantren}

Kepemimpinan di Pesantren dilaksanakan sesuai dasar kepemimpinan Islam adalah sebagai berikut:

1. Tidak mengambil orang kafir atau orang yang tidak beriman sebagai pemimpin bagi orangorang muslim. Sesuai dengan firman Allah QS. An-Nisa' 44:

\footnotetext{
${ }^{5}$ Surahman Amin, Fery Muhammadsyah Siregar. Pemimpin dan Kepemimpinan dalam al-Qur'an (Jurnal Tanzil : Studi Al-Qur'an Vol.1 No.I Oktober 2015), 27-40.

${ }^{6}$ Andam, Manajemen dan Kepemimpinan Kepala Sekolah (Jakarta: Ar-Ruzz Media, 2013), 37.

7 Arvan Pradiansyah, You Are A Leader (Bandung: Mizan Pustaka, 2010), 31-36.
} 


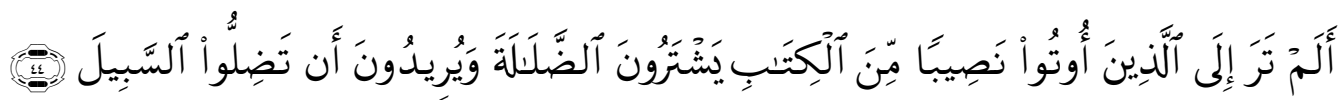

Artinya: Apakah kamu tidak melihat orang-orang yang telah diberi bahagian dari Al kitab (Taurat)? mereka membeli (memilib) kesesatan (dengan petunjuk) dan mereka bermaksud supaya kamu tersesat (menyimpang) dari jalan (yang benar).

2. Tidak mengangkat Pemimpin dari orang-orang yang mempermainkan Islam karena hal ini sudah diingatkan oleh Allah dalam QS. Al-maidah 57:

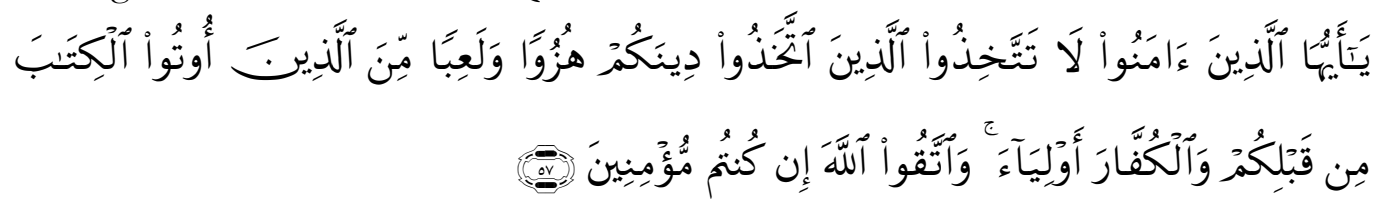

Artinya: Hai orang-orangyang beriman, janganlah kamu mengambil Jadi pemimpinmu, orang-orangyang membuat agamamu Jadi buah ejekan dan permainan, (yaitu) di antara orang-orang yang telah diberi kitab sebelummu, dan orang-orang yang kafir (orang-orang musyrik). dan bertakwalah kepada Allah jika kamu betul-betul orang-orang yang beriman.

3. Pemimpin harus memiliki keahlian dalam bidangnya berkaitan dengan pemberian tugas, wewenang dan fungsi manajemen lainnya. Jika memberikan wewenang kepada yang tidak ahli maka akan mengakibatkan kerusakan kepada organisasi terkait. Dalam sebuah hadist disebutkan

"Apabila suatu urusan diserabkan kepada yang bukan ablinya, maka tumbulah saat kehancurannya"

4. Pemimpin harus bisa diterima, mencintai dan dicintai umatnya, mendoakan dan didoakan oleh umatnya. Hal ini sesuai dengan firman Allah QS. Ali-Imron 159

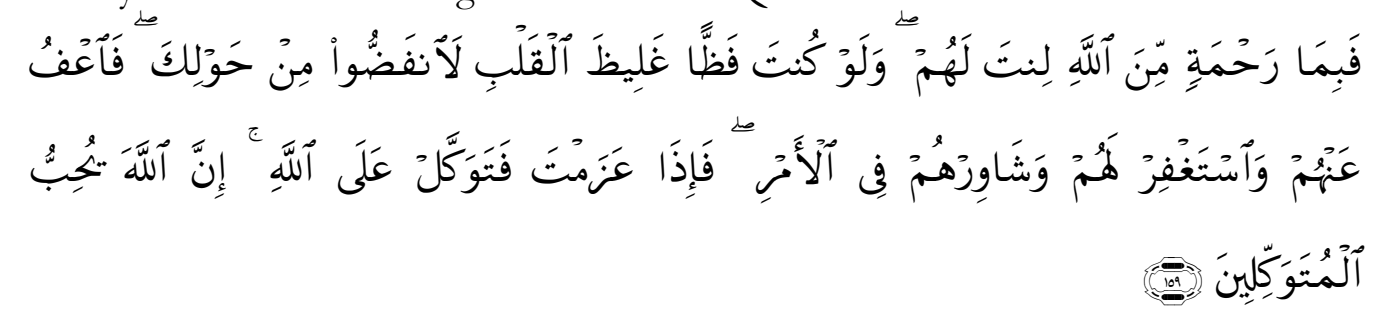

Artinya: Maka disebabkan rahmat dari Allab-lah kamu Berlaku lemah lembut terbadap mereka. Sekiranya kamu bersikap keras lagi berhati kasar, tentulah mereka menjaubkan diri dari sekelilingmu. karena itu ma'afkanlah mereka, mohonkanlah ampun bagi mereka, dan bermusyawaratlah dengan mereka dalam urusan itu kemudian apabila kamu telah membulatkan tekad, Maka bertawakkallah kepada Allah. Sesunggubnya Allah menyukai orang-orang yang bertawakekal kepada-Nya.

5. Pemimpin harus mengutamakan, membela dan mendahulukan kepentingan umat, melakukan supremasi hukum, melaksanakan syariat, berjuang menghapus segala bentuk kemungkaran, kekufuran, kekacauan dan fitnah. Dasar kelima ini sesuai dengan surah Al-Maidah :8.

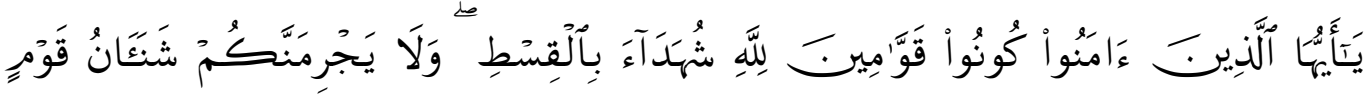

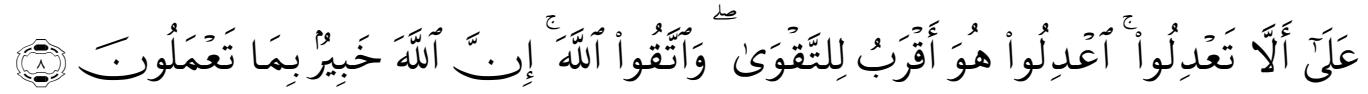

Artinya: Hai orang-orang yang beriman hendaklah kamu Jadi orang-orang yang selalu menegakekan (kebenaran) karena Allah, menjadi saksi dengan adil. dan janganlah sekali-kali kebencianmu terhadap sesuatu kaum, mendorong kamu untuk. Berlaku tidak adil. Berlaku adillah, karena adil itu lebih dekat kepada takwa. dan bertakwalah kepada Allah, Sesunggubnya Allah Maha mengetahui apa yang kamu kerjakan. 


\section{Peta Keragaman'Teori Kepemimpinan Pesantren}

1. Teori Awal Kepemimpinan

Teori-teori awal kepemimpian adalah sebagai berikut:

a. Teori genetis, teori ini sering disebut sebagai the great man theory. Teori ini berasumsi bahwa kapasitas kepemimpinan itu bersifat inheren, bahwa pemimpin besar (great leader) dilahirkan, bukan dibuat (leader are born, not made).

b. Teori sifat (Trait Theories) pada Tahun 1920-1930 an. Serupa konsepsinya dengan teori "The great man" teori sifat mengamsusikan bahwa manusia yang mewarisi sifat-sifat tertentu dan sifat-sifat yang membuat mereka lebih cocok untuk menjalankan fungsi kepemimpinan.

c. Teori perilaku, pada akhir 1940 an sampai pertengahan 1960 an. Teori perilaku kepemimpinan (behavioral theory of leadership) didasari pada keyakinan bahwa pemimpin yang hebat merupakan hasil bentukan atau dapat dibentuk, bukan dilahirkan (leader aramade, not born). ${ }^{8}$ Teori ini melahirkan gaya kepemimpinan demokratis, Autokrasi dan Laisses vaire. ${ }^{9}$

G.R. Terry dalam bukunya "Principle of Management" mengemukakan 8 buah teori kepemimpinan sebagai berikut:

1) Teori otoraktis (the autocratic theory)

2) Teori psikologis (the psychologic theory)

3) Teori sosiologis(thesosiologic theory)

4) Teori supportif (the supportive theory)

5) Teori laissez faire (the laissez faire theory)

6) Teori perilaku pribadi (the personal behavior theory)

7) Teori sifat (the trait theory)

8) Teori situasi (the situational theory) $)^{10}$

2. Teori Kepemimpinan Modern

a. Teori kontigensi, teori ini mengansumsikan bahwa sukses kerja kepemimpinannya itu sendiri tergantung pada sejumlah variabel, termasuk gaya kepemimpinan, kualitas pengikut dan situasi yang mengitarinya.

Teori kontigensi terdiri dari :

1) Model Fiedler, Model kontigensi Fiedler menjelaskan bahwa kinerja kelompok yang efektif tergantung pada kesesuaian antara gaya kepemimpinan dan banyaknya kendali serta pengawasan terhadap situasi itu.

2) Teori kepemimpinan situasi Hersey dan Blanchard. (Situanitional Leadership Theory) adalah kepemimpinan yang diasarkan pada gabungan perilaku hubungan (perhatian terhadap manusi) dan tugas (perhatian terhadap produksi) yang disesuaikan dengan tingkat kesiapan pengikut (kematangan bawahan).11

3) Teori jalur tujuan (Path-Goal Theory) yaitu yang menyatakan bahwa tugas pemimpin adalah membantu pengikutnya mencapai tujuan dan mengarahkan atau memberikan dukungan sesuai kebutuhan untuk memastikan bahwa tujuan mereka sejalan dengan tujuan kelompok atau organisasi. Teori inidikembangkan oleh Robert House. 12

b. Teori partisipatif. Teori-teori kepemimpinan partisipatif menunjukkan bahwa kepemimpinan yang ideal adalah mendorong partisipasi dan dalam anggota kelompok dan membantu anggota kelompok merasa lebih relavan dan berkomitmen terhadap proses pembuatan keputusan. ${ }^{13}$

c. Teori Kepemimpinan Interaktif

\footnotetext{
${ }^{8}$ NurEfendi, Islamic Education Leadership, 20.
}

9Stephen P. Robbins, Mary Coulter, Management Edisi Kedelapan, terj. HarrySlamet (New Jersey:Pearson Education, 2005$), 149$.

${ }^{10}$ Winardi, KepemiminandalamManajemen (Jakarta: RinekaCipta, 2000), 62.

${ }^{11}$ Richard, New Era, 340.

${ }^{12}$ Stephen P. Robbins, Mary Coulter, Management Edisi Kedelapan, terj. HarrySlamet (New Jersey:Pearson Education, 2005), 152-156. ${ }^{13}$ NurEfendi, Islamic, 20. 
Yaitu pemimpin lebih menyukai proses konsesual dan kalaboratif, seta pengaruh muncul lewat hubungan, bukan kekuasaan posisi dan kewenangan formal. ${ }^{14}$

d. Teori Kepemimpinan Karismatik

Yaitu kepemimpinan yang pemimpinnya mampu menginspirasi dan memotivasi orang untuk melakukan sesuatu melebihi kelebihannya, meski duhadapakan dengan halangan dan pengorbanan pribadi. Pemimpin ini mampu menciptakan atmosfir perunahan dan mereka dapat terobsesi dengan ide-ide visioner yang menggairahkan, menstimulasi, dan mendorong orang lain untuk bekerja keras. ${ }^{15}$

e. Teori Kepemimpinan Visioner

Yaitu kepemimpinan yang memposisikan pemimpin sebagai penentu arah, agen perubahan, juru bicara, dan pelatih. ${ }^{16}$

f. Teori KepemimpinanTransformasional

Yaitu mirip kepemimpinan kharismatik akan tetapi perbedaanya pemimpin transformasional memiliki kemampuan istimewa untuk memunculkan inovasi dan perubahan dengan mengetahui kebutuhan dan kepentingan pengikutnya, membantumerekamemandangmasalah lama dengancarabaru. Dan mendorong mereka untuk mempertanyakan status quo. Pemimpin transformational menginspirasi pengikut mereka tidak hanya untuk mempercayai dirinya secara pribadi, namun mempercayai potensi mereka sendiri. ${ }^{17}$ Pemimpin ini dapat mebangkitkan inspirasi anggotanya dan keterkaitan mereka untuk bekerja mencapai tujuan bersama. ${ }^{18}$

g. Teori KepemimpinanTransaksional

Yaitu kepemimpinan yang didasarkan pada pelayanan dari seorang guru misalya, dengan berbagai bentuk upah (penghargaan gaji dan upahi ntrinsik) yang dikontrol oleh pemimpin, setidak-tidaknya pada bagian-bagian tertentu memberikan kekuatan dan penghargaan yang positif dari pada sekedar koreksi. ${ }^{19}$

h. Toeri Kepemimpinan kecerdasan alamiah (Natural Intelligence Leadership)

Yaitu kepemimpinan yang didasarkan pada proses pencarian panjang kita terhadap hakikat penciptaan diri kita serta pemahaman terhadap bentuk kecerdasan manusia yang diterapkan dalam self leadership, team leadership, dan organizational leadership. ${ }^{20}$

i. Teori Kepemimpanan Budaya

Yaitu kepemimpinan yang pemimpinnya membentuk norma dan nilai budaya untuk membangun budaya kinerja tinggi yang diantaranya dengan menggunakan tanda dan simbol, ${ }^{21}$ menciptakan etika budaya, menciptakan budaya yang inovatif, tanggap terhadap konsumen. $^{22}$

j. Teori Kepemimpinan Strategis

Menurut teori ini pemimpin tidak cukup hanya mempunyai visi, juallah visi tersebut dan kembangkan, yang membiarkan orang lain menerjemahkan ke dalam aksi. Implementasi perencanaan strategis memerlukan Monitoring dan evaluasi yang berkelanjutan, yang diikuti dengan kemampuan kreatif untuk memahami perubahan dan bagaimana masalah dapat diatasi secara tepat. ${ }^{23}$

3. Teori Kepemimpinan Islam

a. Teori Kepemimpinan Spiritual

\footnotetext{
${ }^{14}$ RichardL.Daft, New Era of Management, buku 1 edisi 9, TerjTita Maria Kanita (Jakarta:Salembah Empat,2010), 332.

15Richard, New Era, 347.

16Muhammad Syafii Antonio, The Greatest Inspirator dan Motovator (Jakarta: Tazkia, 2014), 166.

${ }^{17}$ Richard, New Era, 349.

${ }^{18}$ Robert S.Baron and Norbert L.Kerr, Group Process, Group Decision,Group Action (Bukingham:Open University Press,2003), 16.

19 Tony BUSH DAN marianne Coleman, Leadership Strategic Management in Education (Yogyakarta: IRCISod, 2006), 73.

${ }^{20}$ Dadang Kadarusman, Natural Intelligence Leadership (Depok: Raih Asa Sukses, 2012), 3.

${ }^{21}$ Richard, New Era, 111.

${ }^{22}$ Stephen P. Robbins, Mary Coulter, Management Edisi Kedelapan, terj. HarrySlamet (New Jersey:Pearson Education, 2005), 72-74.

${ }^{23}$ Tony BUSH DAN marianne Coleman, Leadership Strategic Management in Education (Yogyakarta: IRCISod, 2006), 92.
} 
Yaitu kepemimpinan yang berbasis pada etika religius, kejujuran sejati, fairness, pengenalan dirisendiri, fokus pada amal shaleh, spiritualisme yang tidak dogmatis, bekerja lebih efisien, membangkitkan yang terbaik dalam diri sendiri dan orang lain, keterbukaan menerima perubahan, visionar tetapi fokus pada persoalan didepanmata, doing the raight thing, disiplin tapi tetap fleksibel, santai dan cerdas, dankerendahan hati. ${ }^{24}$

b. Teori Kepemimpinan HatiNurani

Yaitu kepemimpinan yang memiliki karakteristik sebagai berikut Hikmat, Empati, Aktif Rendah hati dan Tanggap (HEART) ${ }^{25}$.Sehingga membentuk rasa saling menghormati, memahami, rasa hubungan kesatuan dan ikatan yang lebih kuat. ${ }^{26}$

c. Teori Kepemimpinan profetik didasarkan pada sifat wajib bagi nabi yaitu shiddiq, amanah, tabligh dan fathanah. ${ }^{27}$

Tabel 3.1 Teori Kepemimpinan

\begin{tabular}{|c|c|c|}
\hline $\begin{array}{c}\text { Teori Awal } \\
\text { Kepemimpinan }\end{array}$ & $\begin{array}{c}\text { Teori Kepemimpinan } \\
\text { Modern }\end{array}$ & Teori Kepemimpinan Islam \\
\hline 1. Teori Genetik & 1. Teori Kontingensi & $\begin{array}{ll}\text { 1. } & \text { Teori Kepemimpinan } \\
\text { Spiritual }\end{array}$ \\
\hline 2. Teori Sifat & a. Model Fidler & $\begin{array}{l}\text { 2. Teori Kepemimpinan Hati } \\
\text { Nurani }\end{array}$ \\
\hline \multirow[t]{11}{*}{ 3. Teori Perilaku } & $\begin{array}{l}\text { b. Kepemimpinan } \\
\text { Situasional }\end{array}$ & $\begin{array}{l}\text { 3. Teori Kepemimpinan } \\
\text { Profetik }\end{array}$ \\
\hline & c. Teori Jalur-Tujuan & \\
\hline & 2. Teori Partisipatif & \\
\hline & $\begin{array}{l}\text { 3. Teori Kepemimpinan } \\
\text { Interaktif }\end{array}$ & \\
\hline & $\begin{array}{l}\text { 4. Teori Kepemimpinan } \\
\text { Karismatik }\end{array}$ & \\
\hline & $\begin{array}{l}\text { 5. Teori Kepemimpinan } \\
\text { Visioner }\end{array}$ & \\
\hline & $\begin{array}{l}\text { 6. Teori Kepemimpinan } \\
\text { Transformasional }\end{array}$ & \\
\hline & $\begin{array}{l}\text { 7. Teori Kepemimpinan } \\
\text { Transaksional }\end{array}$ & \\
\hline & $\begin{array}{l}\text { 8. Teori Kepemimpinan } \\
\text { Kecerdasan Ilmiah }\end{array}$ & \\
\hline & $\begin{array}{l}\text { 9. Teori Kepemimpinan } \\
\text { Budaya }\end{array}$ & \\
\hline & $\begin{array}{l}\text { 10. Teori Kepemimpinan } \\
\text { Strategis }\end{array}$ & \\
\hline
\end{tabular}

\section{Fungsi Nilai Spiritual Kepemimpinan Pesantren}

Nilai spiritual sangat mempengaruhi terhadap pemimpin dalam enam cara yang berbeda yaitu:

1. Nilai mempengaruhi persepsi pemimpin tentang situasi dan problem-problem yang dihadapi.

${ }^{24}$ Tobroni, The Spiritual Leadership (Malang: UMM Press, 2005), 26.

${ }^{25}$ Surbakti, manajemendankepemimipinahatinurani (Jakarta:Gramedia, 2012), 11.

${ }^{26 J a c k}$ Canfield, The success Principles terj. RinaBuntaran (Jakarta: GramediaPustakaUtama, 2006), 478.

${ }^{27}$ Muhammad Syafii Antonio, Prophetic Leadership dan Management Wisdom (Jakarta: Tazkia Publishing, 2005), 2.

156 | Tarbiyatuna: Jurnal Pendidikan Islam;Volume 12, Nomor 2, Agustus 2019 
2. Nilai-nilai yang dimiliki oleh pemimpin mempengaruhi solusi yang diambil olehnya untuk mengatasi masalah yang dihadapi

3. Nilai memerankan peranan yang sangat penting dalam relasi interpersonal.

4. Nilai mempengaruhi persepsi pemimpin tentang kesuksesan individu dan organisasi

5. Nilai dapat menjadikan pemimpin dapat membedakan yang benar dan yang salah dan antara yang etis dan tidak etis.

6. Nilai juga mempengaruhi para pemimpin menerima atau menolak usulan tentang tujuan, target dan program organisasi. ${ }^{28}$

Menurut Steven Covey fungsi kepemimpinan adalah:

1. Merintis (pathfinding)

Dalam hal ini, seorang pemimpin harus selalu punya ide baru untuk diterapkan di pesantren, sehingga menjadi program unggulan dan diversity bagi pesantren.

2. Menyelaraskan (aligning)

Pemimpin harus dapat menyelaraskan ide barunya dengan ide-idenya yang selama ini sudah dijalankan. Hal ini juga berarti seorang pemimpin harus menyelaraskan idenya dengan situasi dan kondisi yang melingkupi pesantren.

3. Memberdayakan (empowering)

Seorang pemimpin juga harus mampu memeberdayakan bawahannya, bukan hanya memberdayakan kemampuan dirinya sendiri

4. Memberikan panutan (modeling)

Pemimpin juga berfungsi sebagai model bagi santrinya dalam berakhlaq karimah.Keteladanan ini merupakan metode pendidikan yang efektif dan terbukti

Kepemimpinan pesantren mengandung falsafah kepemimpinan Gembala 4 M yaitu: ${ }^{29}$

1. Mengenal

2. Mengasuh

3. Mengayomi

4. Melindungi

Disamping itu kepemimpinan pesantren mengandung falsafah Kepemimpinan $4 \mathrm{~K}$ yaitu: ${ }^{30}$

1. Kepekaan

Pemimpin pesantren diharapkan peka terhadap masalah yang muncul di dalam dan di luar pesantren.

2. Kepeduliaan

Kepekaan tidak ada artinya jika tidak memiliki kepedulian untuk membantu menyelesaikannya.

3. Keadilan

Keadilan adalah memberikan hak pada yang berhak menerimanya. Kepedulian harus diwujudkan dengan penuh keadilan.

4. Kejujuran.

Kejujuran akan membawa pada kebaikan baik pada pesantren maupun masyarakat Islam secara luas.

Dari awal tinggal di pesantren santri sudah berlatih memiliki kepekaan dan kepedulian. Sedangkan keadilan dan kejujjuran hanya didapatkan jika santri berkhidmat dalam kepengurusan pesantren.

\footnotetext{
${ }_{28}$ Richard Hughes, Robert C. Ginnet, Gordon J. Curphy, Leadership, Enhancing The Lessons of Experience (Boston: McGraw-Hill, 2002),

${ }^{29}$ E.B Surbakti, Manajemen dan Kepemimpinan Hati Nurani (Jakarta: Kompas Gramedia, 2012), 163-185.

${ }^{30}$ E.B Surbakti, Manajemen, 187-196.
} 


\section{Karakteristik Pemimpin Ideal dalam Pesantren}

Menurut Hagberg Model, Kekuatan personil yang harus dimiliki oleh seorang pemimpin adalah sebagai berikut:

1. Power of lessness

2. Power by association

Kekuatan ini dapat berwujud menjadi keahlian dalam bekerja sama. Kerja sama saling menguntungkan, take and give dengan pihak-pihak yang tepat sangat penting bagi pesantren.

3. Power by Achievement

Prestasi merupakan tolak ukur kualitas santri yang sekaligus menjadi syi'ar pesantren. Pemimpin pesantren diharapkan mampu membentuk budaya berprestasi di kalangan santri.

4. Power by reflection

5. Power by Reflection

6. Power by wisdom. ${ }^{31}$

Sikap bijaksana akan membuat seorang pemimpin bisa diterima oleh semua kalangan. Setiap keputusannya juga akan diterima oleh semua fihak, karena semua fihak merasa diakomodir, diperlakukan sama dan diperhatikan hak-haknya.

Pemimpin yang ideal di pesantren memiliki karakteristik sebagai berikut:

1. Mendegelasikan tanggungjawab, bukan melakukan semuanya sendiri, sehingga manajemen tidak dapat dilaksanakan dengan baik.

2. Menciptakan lingkungan dimana tiap-tiap anggota tim ingin bertanggungjawab

3. Melatih perkembangan kemampuan pribadi

4. Belajar dengan cepat dan mendorong anggota tim untuk belajar dengan cepat juga. ${ }^{32}$

Pemimpin yang ideal harus memenuhi kualiatas pemimpin sebagai berikut: karakter yang baik, kharisma, komitmen yang tinggi, komunikasi yang mantap, kompetensi, keberanian, ketajaman analisis, fokus, kemurahan hati, inisiatif, mendengarkan, semangat yang tinggi, sikap positif, memecahkan masalah, hubungan yang baik, tanggung jawab, tidak merasa terancam, disiplin pribadi, pelayanan yang maksimal, sikap mau belajar dan impian yang tinggi. ${ }^{33}$

Pemimpin yang ideal harus memenuhi hukum-hukum kepemimpinan sebagai berikut:

1. Tidak mengatasi sebuah organisasi seperti yang anggotanya lakukan (Hukum Katup)

2. Memiliki pengaruh yang lebih besar dari pada pengaruh anggotanya (Hukum Pengaruh)

3. Menghargai proses pengembangan orang lebih daripada anggotanya menghargai proses itu (Hukum Proses)

4. Mempersiapkan tim untuk melalui perjalanan mereka dengan lebih baik dari pada yang anggotanya lakukan (Hukum Navigasi)

5. Berkomunikasi dengan lebih efektif dari pada anggotanya dilakukan (Hukum E.F. Hutton)

6. Menciptakan kemampuan untuk terus berkembang dan membawa tim hingga tiba ditingkatan yang lebih tinggi dari pada yang bisa anggotanya (Hukum Momentum Besar)

7. Berdiri diatas landasan kepercayaan yang lebih kokoh daripada landasan kepercayaan anggotanya (Hukum Landasan Mantap)

8. Lebih menghormati orang lain daripada yang bisa anggotanya lakukan (Hukum Kehormatan)

9. Berusaha mengembangkan kepemimpinan lebih cepat daripada yang bisa dilakukan anggotanya (Hukum Instuisi)

10. Menarik lebih banyak pemimpin pada dirinya daripada yang bisa anggotanya lakukan (Hukum Daya Tarik)

\footnotetext{
${ }^{31}$ Ronald Bennett, Elaine Millam, Leadership for Engineers, The Magic of mindset (New York: McGraw-Hill, 2013), 94.

32 John C, Maxwell, The 17 Indisputable Laws of Teamwork (Surabaya: MIC,2012), 309-311.

33 John C, Maxwell, The 21IndispensableQualities of A Leader (Surabaya: MIC, 2012), 1-161.

158 | Tarbiyatuna: Jurnal Pendidikan Islam;Volume 12, Nomor 2, Agustus 2019 
11. Membangun hubungan dengan orang lain lebih baik daripada yang anggotanya lakukan (Hukum Hubungan yang Baik)

12. Mengelilingi diri mereka dengan orang-orang kunci yang lebih kuat daripada yang bisa anggotanya lakukan (Hukum Lingkungan Sepergaulan)

13. Mengahasilkan lebih banyak pemimpin daripada yang bisa anggotanya hasilkan (Hukum Reproduksi)

14. Memberdayakan anggota tim lebih baik daripada yang bisa anggotanya lakukan (Hukum Pemberdayaan)

15. Meraih kemenangan bersama tim lebih sering daripada yang bisa anggotanya lakukan (Hukum Kemenangan)

16. Membuat orang lain jauh lebih mempercayai diri dan visi daripada yang bisa anggotanya lakukan (Hukum Kepercayaan)

17. Menetapakan prioritas dengan lebih efektif daripada yang bisa anggotanya lakukan (Hukum Priotitas)

18. Memeahami dan menggunakan "saat yang tepat" dengan lebih efektif daripada yang bisa anggotanya lakukan (Hukum Waktu yang Tepat)

19. Mengorbankan agenda pribadi mereka lebih daripada yang bisa anggotanya lakukan (Hukum Pengorbanan)

20. Mengembangkan pemimpinan dan organisasi lebih cepat daripada yang bisa anggotanya lakukan (Hukum Pertumbuhan yang Eksplosif)

21. Meninggalkan dampak yang brtahan lebih daripada yang bisa anggotanya tinggalkan (Hukum Warisan) ${ }^{34}$

Pemimpin seharusnya memiliki identitas TOPS yaitu: ${ }^{35}$

1. Tanggung jawab.

Tanggung jawab merupakan identitas terpenting bagi pemimpin, karena dengan tanggung jawab akan muncul sikap pemimpin yang baik lainnya, seperti adil, jujur dan bijaksana

2. Otoritas,

3. Perbuatan

4. Status

\section{Arah Pengembangan Kepemimpinan Pesantren}

Kepemimpinan pesantren seharusnya memiliki arah pengembangan pada terbentuknya:

1. Ummat yang bersatu (ummatan wahidah)

2. Ummat yang moderat (ummatan wasathan)

3. Ummat yang terbaik (khoiru ummah)

4. Negara yang makmur (baldatun thoyyibatun)

5. Ummat yang lurus dijalan Allah (ummatan muqtasidab). ${ }^{36}$

Kepemimpinan pesantren dapat juga diarahkan dan dikembangkan menuju hal-hal berikut:

1. Membentuk ummah (takwinul ummah)

2. Membentuk kepribadian (takwin Asy-syakhshiyyah)

3. Membentuk semangat berjamaah (takwin ruub al-jamaa'ab)

4. Gerakan penyelamatan (barakah al-inqaads)

5. Orang yang mendapatkan petunjuk (al-mubtaduun)

6. Kesuksesan (al-falah)

${ }^{34}$ John C, Maxwell, The 17 Indisputable Laws of Teamwork (Surabaya: MIC,2012), 309-311.

35 E.B Surbakti, Manajemen, 223-227.

36Ali Nurdin, Quranic Society (Jakarta: Erlangga, 2006), 100.

${ }^{37}$ Irwan Prayitno, Datuak Rajo Bandaro Basa, Kepribadian Dai (Jakarta: Pustaka Tarbiatuna, 2005), 291. 
Prinsip-prinsip kepemimpinan profetik sebagai berikut $:^{38}$

1. Prinsip Tauhid

2. Prinsip Syura (musyawarah)

3. Prinsip al-Adalah (adil)

4. Prinsip al-Hurriyah (kebebasan)

Kepemimpinan profetik dapat diterapkan dengan menggunakan strategi sebagai berikut:

1. Pilihlah langkah strategik (Be Strategic)

2. Bekerja samalah (Find Champions/Make Alliance)

3. Bersikaplah sikap fleksibel dengan menggunakan tahapan-tahapan yang strategik (Be FlexibleUse a Range of Strategies)

4. Dapatkan kepercayaan dari orang lain (Be Credible)

5. Ciptakan komunikasi dengan baik (Comunicate)

6. Manajlah dan dukunglah tim kamu (Manage and Support Your Team)

7. Lakukan penelitian yang berfokus pada pekerjaan dari unit tertentu (Take a Research Focus to the Work of the Unit)..$^{39}$

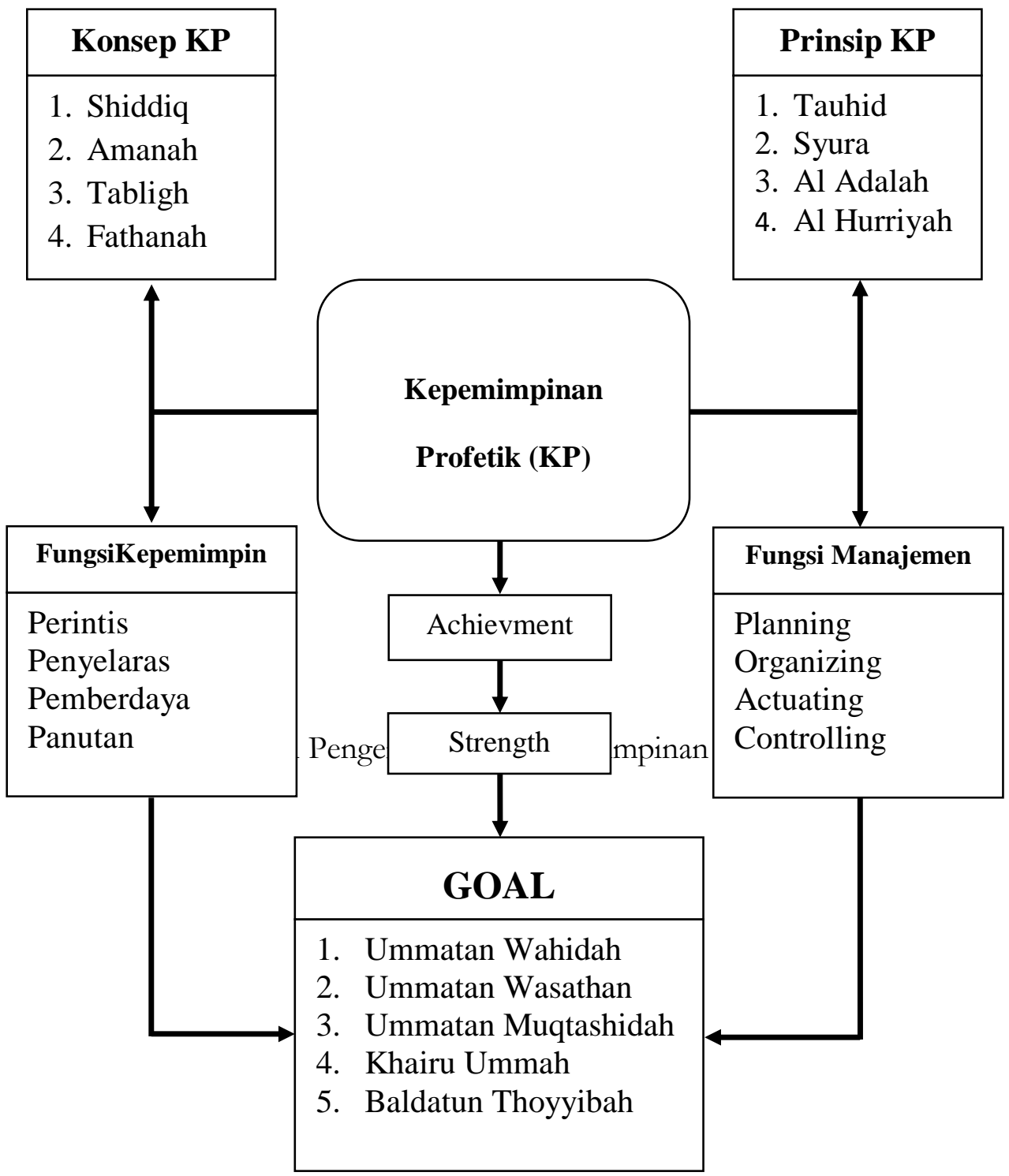

38Shoni Rahmatullah Amrozi, The Power Of Rasulullah's Leadership (Yogyakrta: Sabil, 2012), 142-157.

${ }^{39}$ David Baume dan Peter Kahn, Enhancing Staff and Educational Development (London: Routledge Falmer, 2004), 45-51. 


\section{Kesalahan-Kesalahan dalam Memimpin Perubahan}

Beberapa kesalahan dalam memimpin perubahan adalah sebagai berikut:

a. Tidak memiliki rasa mementingkan orang lain dan organisasi yang cukup besar.

Di pesantren kesalahan dalam memimpin transformasi budaya dapat diminimalisasi. Oleh karena kyai memiliki sense of belonging (rasa memiliki) yang tinggi terhadap pesantren yang dipimpinnya dan dirintisnya maka kyai cenderung mendahulukan kepemimpinan pesantren dari pada kepemimpinan pribadi dan keluarganya.

Hal ini dapat menimbulkan dampak negatif yaitu banyak tanggungjawab terhadap pesantren yang tidak terpenuhi sehingga mengganggu jalannya manajemen pesantren yang pada akhirnya dapat memicu konflik pesantren. Permasalahan ini dapat diatasi dengan memperjelas etika pesantren dan berpegang teguh pada etika tersebut.

b. Tidak membentuk koalisi yang dapat mengarahkan organisasi dengan kuat

Pada zaman sekarang, pesantren yang membentuk koalisi (kerjasama) dengan pihak-pihak tertentu dengan baik, akan mengalami perkembangan yang pesat. Koalisi tersebut dapat dilakukan dalam bidang ekonomi, pendidikan, politik dan sosial.

Jika hal ini tidak dilakukan maka pesantren akan mengalami perkembangan yang lambat. Namun demikian hal ini dapat diatasi dengan membentuk koalisi dengan pihak tertentu sesuai dengan kebutuhan baik koalisi dengan sesama pesantren atau lembaga yang lain.

c. Kurang tepat dalam merumuskan visi dan misi.

Banyak pesantren dalam merumuskan visi dan misinya tidak sesuai dengan kebutuhan dan tuntutan masyarakat. Bahkan tidak mempertimbangkan situasi dan kondisinya. Visi dan misi hanya didasarkan pada ideologi para pendirinya. Hal ini berdampak pada pesantren tidak memiliki distingsi dan menejemen pesantren dapat berjalan kearah yang tidak diinginkan sehingga dapat menyebabkan kegagalan pesantren. Kondisi ini dapat diatasi dengan memperjelas visi dan misi pesantren dengan memunculkan diistingsi pesantren dan kegiatan harus mengarah pada visi misi tersebut dan memperkuat distingsinya.

Kesalahan-kesalahan yang dilakukan oleh beberapa pesantren seperti diatas, dapat menimbulkan dampak tertentu, baik kepada internal pesantren maupun eksternal pesantren. Karena itulah perlu solusi yang tepat untuk mengatasinya. Hal ini dapat diilustrasikan sebagai berikut: 
Gambar 3. Kesalahan -kesalahan dalam memimpin

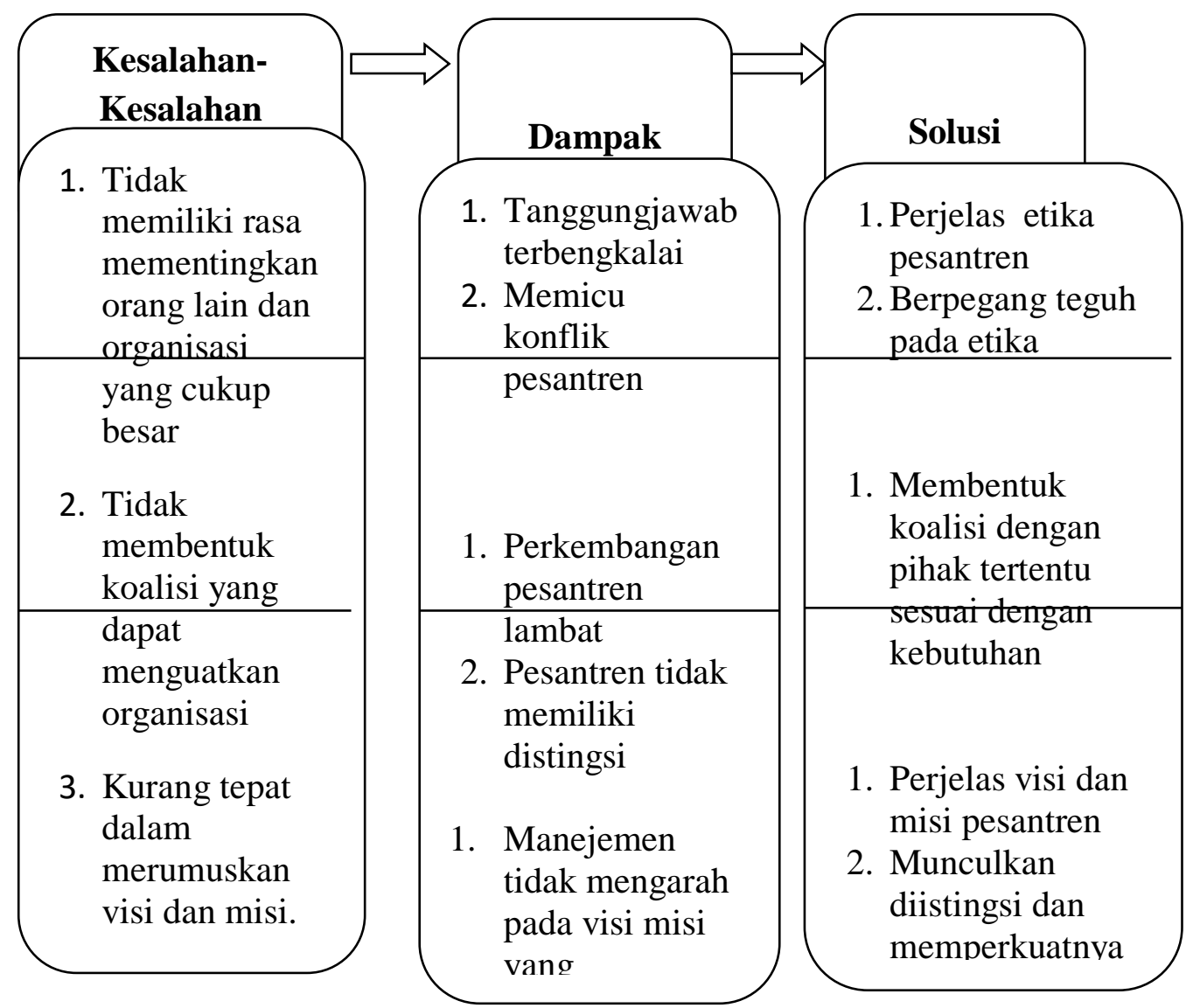

Sumber data: Dokumentasi Peneliti

\section{Analisis Kepemimpinan Pesantren dan Perubahan sosial}

Dalam menghadapi perubahan sosial, kepemimpinan pesantren diharapkan bisa melakukan prinsip-prinsip kepemimpinan profetik yang didasarkan pada sifat wajib bagi nabi yaitu shiddiq, amanah, tabligh dan fathanah. Shiddiq akan melahirkan intergitas sehingga terbentuk keunggulan personil. Amanah dapat melahirkan pribadi yang dapat dipercaya. Tabligh melahirkan pribadi yang komunikatif sehingga terbentuklah kepemimpinan visioner. Fathanah melahirkan kompetensi sehingga terbentuk profesionalisme. ${ }^{40}$

Dalam menghadapi perubahan sosial, kepemimpinan pesantren cenderung mencapai tujuannya, karena kyai dan keluarganya, para ustadz dan santri tinggal dalam satu area pesantren, sehingga mempermudah jalannya kepemimpinan yang sarat dengan proses pendidikan dan pengajaran. Di samping itu disebabkan karena para santri dididik dan dilatih untuk memiliki keahlian sosial sebagai berikut:

1. Listening yaitu mendengarkan masukan, keluhan, kritikan orang lain

2. Sharing yaitu berbagi suka, duka, informasi, pengalamam dan pengetahuan

3. Manners

4. Emphaty ${ }^{41}$ yaitu ikut merasakan perasaan orang lain, sebagai bukti kasih sayang sdan satu gerak perjuangan

Dalam hal kepemimpinan pesantren, seorang pemimpin harus menerapkan The Spiritual Leadership yang secara garis besar adalah sebagai berikut: ${ }^{42}$

${ }^{40}$ Muhammad Syafii Antonio, Prophetic Leadership dan Management Wisdom (Jakarta: Tazkia Publishing, 2005), 2.

${ }^{41}$ Carol Cummings, Winning Strategies for Classroom Management (Alexandria: ASCD, 2000), 97.

162 | Tarbiyatuna: Jurnal Pendidikan Islam;Volume 12, Nomor 2, Agustus 2019 
1. Melakukan konsolidasi dengan niat yang suci yaitu dengan memulai dari niat diri sendiri, membangun niat secara bersama, mempertahankan niat, niat dan budaya organisasi.

2. Membangun persaudaraan dan kolaborasi yaitu dengan menyatukan hati, membangun kolaborasi, dan membangun sinergi.

3. Membangun integritas yaitu cara membangun integritas, integritas budaya organisasi yang sehat.

4. Membangun rasa syukur dan kesabaran yaitu syukur dan sabar sebagai modal kepemimpinan, bagaimana membangun syukur dan sabar, rasa syukur dan budaya organisasi.

Dalam kaitannya dengan kepemimpinan spiritual, dan kepemimpinan profektik Abdul

Basit, Dosen Jurusan Dakwah STAIN Purwokerto melakukan Studi Kepemimpinan Spiritual di

STAIN Purwokerto. Adapun hasil temuannya dapat disimpulkan sebagai berikut:

1. adanya nilai-nilai spiritual yang dipegang teguh oleh pemimpin dan dijadikan sebagai ideologi atau keyakinan untuk memotivasi dirinya dan orang lain. Nilai-nilai spiritual yang dimaksudkan adalah nilai kebersamaan, keyakinan atau tekad yang kuat, dan taat pada aturan.

2. Membangun tradisi kepemimpinan spiritual yang tercermin dalam tindakan yang dilakukan oleh pemimpin dalam mencapai visi yang ingin dicapai. Proses pembiasaannya dilakukan dengan berpegang teguh pada nilai-nilai spiritual yang diusungnya. Kemudian diimplementasikan dengan mengeluarkan program program unggulan yang didukung dengan kebijakan-kebijakan strategis yang dilakukan secara intensif sehingga menjadi agenda rutin dari civitas akademika dan tenaga kependidikan serta dapat menghasilkan budaya organisasi yang sehat dan berkualitas.

3. Budaya organisasi ditumbuhkembangkan dengan cara membangun suasana yang dinamis, penuh kekeluargaan, kerjasama, terbuka dan saling menghargai baik dari sisi spiritual, intelektual dan profesional. ${ }^{43}$

\section{Daftar Pustaka}

Amin, Surahman. Fery Muhammadsyah Siregar. Pemimpin dan Kepemimpinan dalam al-Qur'an. Jurnal Tanzil : Studi Al-Qur'an Vol.1 No.I Oktober 2015.

Amrozi, Shoni Rahmatullah. 2012. The Power Of Rasulullab's Leadership. Yogyakrta: Sabil.

Andam. 2013. Manajemen dan Kepemimpinan Kepala Sekolah. Jakarta: Ar-Ruzz Media

Antonio, Muhammad Syafii. 2005. Prophetic Leadership dan Management Wisdom. Jakarta: Tazkia Publishing.

Antonio, Muhammad Syafii. 2005. Prophetic Leadership dan Management Wisdom. Jakarta: Tazkia Publishing.

Antonio, Muhammad Syafii. 2014. The Greatest Inspirator dan Motovator. Jakarta: Tazkia, ${ }^{1}$ Richard,New Era.

Baron, Robert S. and Norbert L.Kerr. 2003. Group Process, Group Decision,Group Action. Bukingham:Open University Press.

\footnotetext{
42 Tobroni, The Spiritual Leadership; Pengefektifan Organisasi Noble Industri Melalui Prinsip-prinsip Spiritual Etis (Malang, Universitas Muhammadiyah, 2005), 93-123.

43 Abdul Basit, Habitual Action Dalam Kepemimpinan Spiritual; Studi Kepemimpinan Spiritual di STAIN Purwokerto; Jurusan

Dakwah STAIN Purwokerto KOMUNIKA ISSN: 1978-1261 Vol.7 No.1 Januari - Juni 2013 pp.
} 
Basit, Abdul. Habitual Action Dalam Kepemimpinan Spiritual; Studi Kepemimpinan Spiritual di STAIN Purwokerto; Jurusan Dakwah STAIN Purwokerto KOMUNIKAISSN: 1978-1261 Vol.7 No.1 Januari - Juni 2013 pp.

Baume, David dan Peter Kahn. 2004. Enhancing Staff and Educational Development. London: Routledge Falmer.

Bennett, Ronald Elaine Millam. 2013. Leadership for Engineers, The Magic of mindset. New York: McGraw-Hill.

Bush, Tony dan marianne Coleman. 2006. Leadership Strategic Management in Education. Yogyakarta: IRCISod.m.

Daft, RichardLNew Era of Management, buku 1 edisi 9, TerjTita Maria Kanita (Jakarta:Salembah Empat,2010), 332

Canfield, Jack. 2006. The success Principles terj. RinaBuntaran. Jakarta: Gramedia Pustaka Utama.

Cummings, Carol. 2000. Winning Strategies for Classroom Management. Alexandria: ASCD.

E.B Surbakti. 2012. Manajemen dan Kepemimpinan Hati Nurani. Jakarta: Kompas.

Efendi, Nur. 2015. Islamic Education Leadership. Yogyakarta:Kalimedia.

G. Yukl. 1989. Leadership In Organization (Second Edition). Englewood Cliffs- New Jersey: Prentice Hall Inc.

Hersey, Paul dan Kennet H. Blanchard. 1977. Management of Organizational Behavior. Utilizing Human Resource. Englewood Cliffs- New Jersey: Prentice Hall Inc.

Hughes, Richard, Robert C. Ginnet, Gordon J. Curph. 2002. Leadership, Enhancing The Lessons of Experience. Boston: McGraw-Hill.

Kadarusman, Dadang. 2012. Natural Intelligence Leadership. Depok: Raih Asa Sukses.

Maxwell, John C. 2012. The 17 Indisputable Laws of Teamwork. Surabaya: MIC.

Maxwell, John C. 2012. The 21IndispensableQualities of A Leader. Surabaya: MIC.

Nurdin, Ali. 2006. Quranic Society. Jakarta: Erlangga.

Pradiansyah, Arvan. 2010. You Are A Leader. Bandung: Mizan Pustaka.

Prayitno, Irwan, Datuak Rajo Bandaro Basa. 2005. Kepribadian Dai. Jakarta: Pustaka Tarbiatuna.

Robbins, Stephen P. 2005. Mary Coulter, Management Edisi Kedelapan, terj. Harry Slamet. New Jersey:Pearson Education.

Surbakti. 2012. Manajemen dan Kepemimipinan Hati Nurani. Jakarta:Gramedia.

Tobroni. 2005. The Spiritual Leadership. Malang: UMM Press.

Tobroni. 2005. The Spiritual Leadership; Pengefektifan Organisasi Noble Industri Melalui Prinsip-prinsip Spiritual Etis. Malang, Universitas Muhammadiyah. 
Walters, J. Donald, Herb Cohen, Dave Johnson. 2013. Great Leadership. Semarang: Dahara Prize.

Winardi. 2000. KepemiminandalamManajemen. Jakarta: Rineka Cipta. 